\title{
The Objective Test of Cochlear Dead Region Using Acoustic Change Complex: A Preliminary Report
}

\author{
Soojin Kang ${ }^{1,2 *}$, Juhyun Han ${ }^{3 *}$, Jihwan Woo ${ }^{1}$, Hee Sung Park ${ }^{2}$, \\ Il Joon Moon ${ }^{2,4}$, Kyusung Choi ${ }^{3}$, and Sung Hwa Hong ${ }^{2,3}$ \\ ${ }^{I}$ Department of Biomedical Engineering, University of Ulsan, Ulsan; and ${ }^{2}$ Hearing Research Laboratory, Samsung Medical Center, \\ Seoul; and ${ }^{3}$ Department of Otorhinolaryngology-Head and Neck Surgery, Samsung Changwon Hospital, Sungkyunkwan University \\ School of Medicine, Changwon; and ${ }^{4}$ Department of Otorhinolaryngology-Head and Neck Surgery, Samsung Medical Center, \\ Sungkyunkwan University School of Medicine, Seoul, Korea
}

\section{Acoustic Change Complex에 기반한 와우소실영역 검사의 객관적인 방법 제시를 위한 예비 연구}

강수진 ${ }^{1,2 *} \cdot$ 한주현 ${ }^{3 *} \cdot$ 우지환 ${ }^{1}$ 박희성 $\cdot$ 문일준 ${ }^{2,4} \cdot$ 최규성 ${ }^{3} \cdot$ 홍성화 ${ }^{2,3}$

울산대학교 의공학과, ${ }^{1}$ 삼성서울병원 청각연구실, ${ }^{2}$ 성균관대학교 의과대학 삼성창원병원 이비인후과학교실, ${ }^{3}$

성균관대학교 의과대학 삼성서울병원 이비인후과학교실 ${ }^{4}$

\author{
Received October 17, 2017 \\ Revised December 22, 2017 \\ Accepted December 28, 2017 \\ Address for correspondence \\ Sung Hwa Hong, MD, PhD \\ Department of Otorhinolaryngology- \\ Head and Neck Surgery, \\ Samsung Changwon Hospital, \\ Sungkyunkwan University \\ School of Medicine, \\ 158 Paryong-ro, Masanhoewon-gu, \\ Changwon 51353, Korea \\ Tel $+82-55-233-8000$ \\ Fax $+82-55-233-8004$ \\ E-mail hongsh@skku.edu \\ *These authors contributed equally \\ to this work.
}

Background and Objectives Cochlear dead region (CDR) is a region in the cochlear where hearing loss has occurred due to damage to the inner hair cells and/or neurons. Recently, a subjective test involving a pure-tone test in the presence of threshold-equalizing noise (TEN) was introduced to identify CDR. However, for uncooperative patients, such a subjective method would be unsuitable and objective methods would be needed instead to detect CDR. The acoustic change complex (ACC) is an evoked potential elicited by changes in the ongoing sound. In this study, we developed an objective method of identifying CDR by combining ACC response with a TEN test, namely the TEN-ACC test, and investigated its feasibility in normal-hearing listeners. Subjects and Method Ten normal-hearing subjects participated in this study. All subjects underwent both behavioral TEN test and electrophysiological TEN-ACC test. The stimuli for the TEN-ACC test consisted of TEN and embedded pure tones with different frequencies/signals to noise ratios (SNRs). To identify the thresholds, the range SNR of stimulation was varied from 0 to $20 \mathrm{~dB}$, in stages of $4 \mathrm{~dB}$.

Results The ACC responses of all subjects who participated in this study were well elicited by stimuli developed for the TEN-ACC test. We confirm that the pure-tones embedded in TEN elicited the objective ACC response.

Conclusion The results of this study suggest that the novel TEN-ACC test can be applied to evoke ACC in normal-hearing listeners. Future research should incorporate hearing-impaired listeners to determine the feasibility of the TEN-ACC test as an objective method to identify CDR. Korean J Otorhinolaryngol-Head Neck Surg 2018;61(11):573-9

Key Words Acoustic change complex · Cochlear dead region ·

Electrophysiological approach $\cdot$ Hearing loss $\cdot$ Threshold-equalizing noise.

\section{서 론 \\ 재하는 내유모세포 또는 청신경의 손상으로 인해 소리 전달 기능을 상실한 영역을 일컫는다. ${ }^{1,2)}$ 난청 환자에서 와우소실 와우소실영역(cochlear dead region)이란 달팽이관 내에 존 영역이 특정 주파수 대역에서 존재한다면 해당 주파수 부위}

This is an Open Access article distributed under the terms of the Creative Commons Attribution Non-Commercial License (https:/creativecommons.org/licenses/by-nc/4.0) which permits unrestricted non-commercial use, distribution, and reproduction in any medium, provided the original work is properly cited. 
기저막이 큰 폭으로 진동한다 하더라도 그 정보가 중추 청각 신경로로 전달되지 않게 된다. 난청 환자는 보청기를 통해서 주파수별 소리 신호를 증폭하여 청력 손실에 대한 보상을 기 대하는데, 이러한 와우소실영역을 지닌 환자에서는 보청기의 증폭 효과를 기대하기 힘들다. 따라서 와우소실영역이 어떤 주파수 대역에 존재하는지에 대한 정확한 정보는 임상에서 난청 환자의 청력 보상을 위한 보청기 적합의 방법을 결정하 는 데 중요한 역할을 할 수 있다.,3-5)

와우소실영역을 탐지하는 행동학적 검사 방법으로 청력역 치등가소음 검사법(threshold-equalizing noise test, TEN test)이 있다.6,7) 청력역치등가소음(TEN)이란 소음이 존재할 때 그 크기와 동일한 순음의 크기가 소음 하 순음 가청 역치 가 되도록 만들어진 소음으로, $500 \mathrm{~Hz}$ 부터 $4000 \mathrm{~Hz}$ 까지의 주파수 성분을 가진 소음이다. 순음 청력검사 결과를 절대 역치, 청력역치등가소음 하 순음 가청 역치를 차폐 역치라고 하였을 때, 첫 번째 차폐 역치가 절대 역치보다 $10 \mathrm{~dB}$ 이상 크 고, 두 번째로 차폐 역치가 청력역치등가소음의 크기보다 10 $\mathrm{dB}$ 이상 큰 경우 즉, 첫 번째 조건과 두 번째 조건을 동시에 만족하는 경우 해당 순음의 주파수 대역에 와우소실영역이 있다고 할 수 있다. 이 검사법은 와우소실영역을 탐지하는 간 단하고 유용한 검사 방법이지만, 검사 대상자의 행동 반응을 요구하기 때문에 적절한 행동 반응을 보일 수 없는 대상자에 대해서는 검사 진행이 어려운 단점이 있다.

따라서 와우소실영역을 탐지하는 객관적인 방법의 개발이 필요하다. 일반적으로 전기생리학적 반응을 통해 객관적인 검 사를 진행할 수 있는데 그 중 대표적인 것이 acoustic change complex(ACC)이다. 지속되는 소리의 어느 시점에서 어떠한 변 화가 생기면 발생하는 뇌파 반응을 ACC 반응이라고 한다. ${ }^{8)}$ 즉, $\mathrm{ACC}$ 반응은 주파수 변화, 소리의 시간적 변화, 소리 크기 의 변화, 말소리의 변화 등에 의해서 유발된다. ${ }^{9-11)}$ 한 연구에 서는 청각 분별력을 심리 음향학적 방법과 전기생리학적 방법 으로 평가하여 두 방법의 결과를 비교하였으며, ACC 반응이 주파수 및 소리 크기 분별력을 평가하기 위한 지표로 사용될 수 있다고 제안하였다.11) 이렇듯, 여러 연구에서 ACC 반응을 지표로 활용하여 피험자의 청각 능력을 객관적으로 평가할 수 있다고 제안하였다. 또한, $\mathrm{ACC}$ 반응은 좋은 신호대 잡음 비(signal to noise ratio, SNR)와 검사-재검사 신뢰도를 가지 고 있다. ${ }^{12)}$

$\mathrm{ACC}$ 반응은 소리의 변화에 대해 유발되는 반응이므로, 청력역치등가소음의 크기보다 큰 순음을 제시하였을 때 소 리 크기의 차이와 주파수 성분의 차이로 인해서 $\mathrm{ACC}$ 반응이 확연하게 유발될 수 있을 것이라 가정하였다. 또한, 나중에 제 시되는 순음의 크기에 따라서 유발되는 ACC 반응의 진폭 등
의 특성이 달라질 것이고 이를 활용하여 소리의 변화를 인지 하기 시작하는 역치를 찾을 수 있을 것이라 기대하였다.

연구의 궁극적인 목표는 TEN test에서 사용한 음원을 변 형하여 다양한 신호대 잡음비를 가져 $\mathrm{ACC}$ 를 유발할 수 있 는 새로운 음원을 개발하고 전기생리학적 반응인 ACC 반응 을 활용하여 와우소실영역을 탐지할 수 있는 객관적인 방법 으로써 TEN-ACC test를 개발하는 것이다. 이를 위한 예비 연구로서 본 연구에서는 정상인을 대상으로 $\mathrm{ACC}$ 를 이용한 와우 소실영역 탐지가 가능한지 확인해 보고자 하였다.

본 연구자들은 청력역치등가소음의 배경 잡음이 있는 환 경에서 청력역치등가소음의 크기보다 큰 순음을 제시하였을 때 유발전위 $\mathrm{ACC}$ 가 발생하고 잡음 대비 순음의 크기가 작 아질수록 $\mathrm{ACC}$ 반응의 진폭이 작아질 것이므로 반응이 더 이상 보이지 않는 단계의 직전의 단계를 청력역치등가소음 차폐 역치로 평가할 수 있다고 가설을 세웠다.

\section{대상 및 방법}

대상자는 양측 청력 검사상 250 8000 Hz순음의 청력 역치 가 $25 \mathrm{~dB} \mathrm{HL}$ 이하인 정상 청력인 10명을 대상으로 하였다. 모집된 대상자들의 나이는 평균 27.22세(20 33세, SD: 4.54) 이다. 임상시험은 행동학적 검사법인 TEN test와 전기생리학 적 검사법인 TEN-ACC test를 모두 진행하였다. 본 연구는 임 상연구윤리위원회(IRB)의 임상 시험 승인(No. 2014-03-059) 을 받았으며, 모든 피험자는 서면 동의를 한 후 임상 연구에 참여하였다.

행동학적 검사법인 TEN test는 Brian Moore 교수팀이 개 발한 검사법을 그대로 적용하였다. 이 검사법은 배경 잡음으 로 청력역치등가소음이 존재할 때, TEN 음원의 크기를 고정 하고 순음의 신호대 잡음비(SNR)를 조절하여 제시하면서 순음을 감지하는 최소 역치를 찾는 검사법이다. 모든 연구 참여 피험자에게 제시된 청력역치등가소음의 크기는 $40 \mathrm{~dB}$ $\mathrm{HL} / \mathrm{ERBN}$ 로 고정하였다. 자극음은 순음 청력검사 기기와 ER-3A 삽입형 이어폰을 사용하여 제시하였고, 모든 검사는 차폐실에서 진행되었다. TEN test는 양쪽 귀 모두 진행하였 고, 그 중 무작위로 한 쪽 귀를 선택하여 전기생리학적 검사 를 진행하였다.

자극음 제시는 Neuroscan STIM2 system과 ER-3A 삽입 형 이어폰을 이용하여 진행하였고, 자극음에 대한 electroencephalography(EEG) 측정은 Neuroscan Scan4.5, SynAmp2 system을 이용하여 진행하였다. EEG가 기록되는 동안 피험 자는 어두운 차폐실 안의 안락의자에 편안한 자세로 앉아 소리는 나오지 않고 자막이 있는 영화를 시청하였다. 
피험자의 피로도 및 검사의 집중도를 고려하여 전 주파수 대역에서 검사를 진행하는 대신, 두 주파수 대역에서 검사를 실시하였다. 두 주파수는 청력도의 가장 기본적인 주파수인 $1 \mathrm{kHz}$ 와 와우소실영역이 잘 발생한다고 알려진 고주파수 대 역 $4 \mathrm{kHz}$ 를 선택하였다. 전기생리학적 검사인 TEN-ACC test 를 위해 제작한 자극의 형태는 Fig. 1 과 같이 TEN 음원만 있 는 부분 1 초, $\mathrm{TEN}$ 과 순음이 있는 부분 1 초로 총 2 초로 제 작하였다. 자극 간 간격은 2 초로 설정하였다. 즉, 한 자극음 의 시작에서 다음 자극음의 시작까지 걸리는 시간은 4초이 다. 청력역치등가소음 대비 순음의 크기는 $0,4,8,12,16,20$ $\mathrm{dB}$ SNR의 단계로 제시하였으며, 각 조건 당 자극음을 100 번 반복 측정하여 $\mathrm{EEG}$ 파형을 취득하였다. $\mathrm{EEG}$ 파형 측정

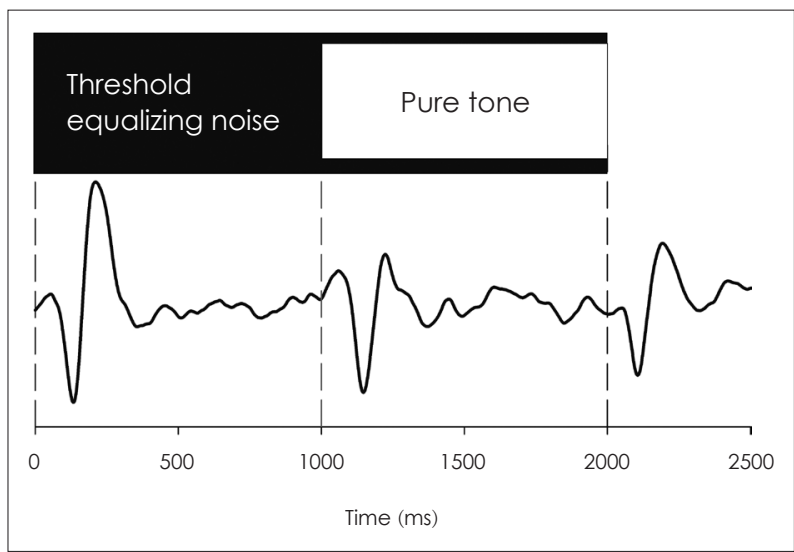

Fig. 1. Example stimulus of the TEN-ACC test and response. The stimulus consists of a TEN only and a pure tone with TEN parts. After the stimulus is presented, onset response (first dashed line) and the ACC response (second dashed line) are evoked. TEN: threshold-equalizing noise, ACC: acoustic change complex.
을 위한 전극은 다음과 같이 부착하였다. 기록 전극은 국제 10 20 전극 배치법에 의해 정의된 $\mathrm{Cz}$ 위치, 기준 전극은 측정 귀 반대 측의 유양돌기, 접지 전극은 이마 부분(Fpz)에 위치 하였고, 눈의 움직임에 의한 잡음 제거를 위해 왼쪽 눈의 위, 아래, 양옆의 관자놀이 부근에 전극을 부착하였다. 전극의 임피던스는 $5000 \Omega$ 이하로 유지하도록 하였고, 전극과 전극 사이의 임피던스 차이는 $2000 \Omega$ 이하로 유지했다.

실시간 습득되는 $\mathrm{EEG}$ 파형은 10배 증폭시키고 밴드패스 필터 $(0.1 \sim 100 \mathrm{~Hz})$ 를 적용하였고, 1 초에 1000 번의 샘플을 기 록하여 $\mathrm{EEG}$ 파형을 취득하였다. $\mathrm{EEG}$ 측정 후의 데이터 처 리는 다음과 같다. 먼저, 100 번의 모든 반복 구간에 대해서 눈움직임에 대한 잡음을 제거하였다. 그 후에 자극음 시작점 (onset) 이전의 $-100 \mathrm{~ms}$ 부터 시작점 이후의 $2500 \mathrm{~ms}$ 까지의 구간을 추출해내고, 기준치 보정 처리를 하였다. 밴드패스 필 터(12 dB/octave)를 적용하여 1 30 Hz의 성분만 통과시킨 후, 100 번의 반복 측정을 모두 더하여 산술 평균화한 $\mathrm{EEG}$ 파형을 구하였다. 파형의 평활화(smoothing)를 위하여 40 $\mathrm{ms}$ 의 boxcar 필터를 적용한 후에, 모든 피험자에 대한 전체 평균(grand-average waveform)을 구하였다. ACC 반응의 유무는 두 명의 청각사가 모두 동의한 경우에만 존재한다고 판단하였다.

습득된 $\mathrm{EEG}$ 파형을 위에 기술한 바와 같이 분석하여 본 연구에서 사용한 자극음에 대해 ACC 반응이 유발되는지 확인하고, 자극 크기 단계에 따른 $\mathrm{ACC}$ 반응의 유무를 확인 하여 역치를 평가하였다.

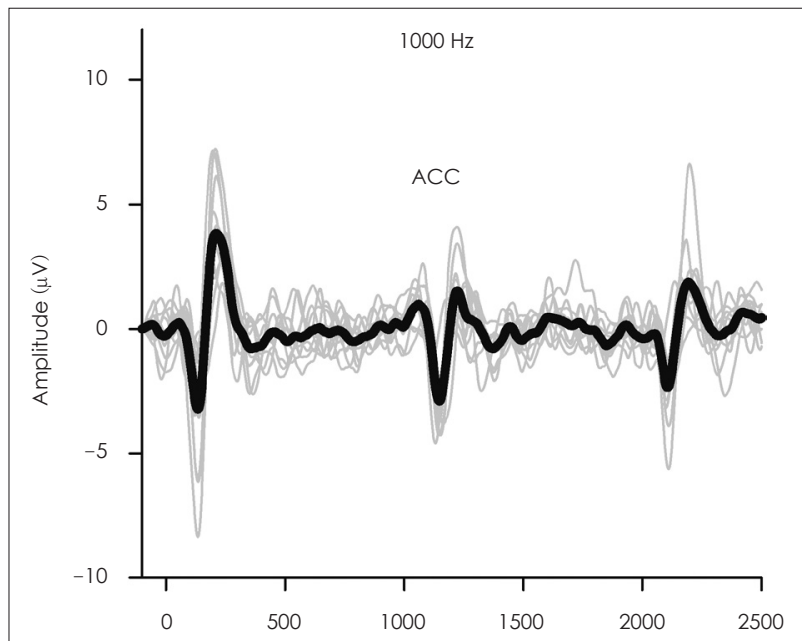

A

Time (ms)

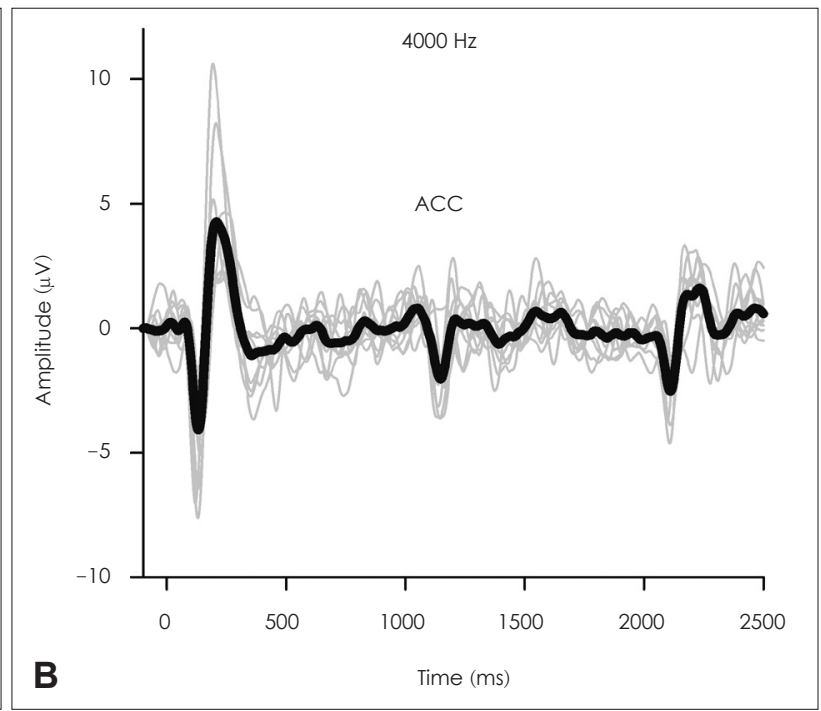

Fig. 2. The graph shows electroencephalography response with stimulus of $20 \mathrm{~dB}$ signal to noise ratios at $1000 \mathrm{~Hz}(\mathrm{~A})$ and $4000 \mathrm{~Hz}$ (B). The gray lines display individual data, and the thick black line indicates grand-average waveform. The ACC responses were well evoked in all subjects. ACC: acoustic change complex. 


\section{결 과}

연구에 참여한 10 명의 모든 피험자에게서 뚜렷한 $\mathrm{ACC}$ 반 응을 관찰할 수 있었다. $1000,4000 \mathrm{~Hz}$ 의 순음 자극음에 대 해 모든 피험자에서 취득한 파형을 Fig. 2에 나타내었다. 청 력역치등가소음이 배경잡음으로 존재할 때 순음을 제시하는 크기가 가장 큰 조건인 $20 \mathrm{~dB} \mathrm{SNR}$ 인 경우의 파형을 그린 것 이다. 가는 회색 선은 개인별 파형을 나타내며, 10 명의 모든 피험자의 파형을 합하여 평균화한 전체 평균 파형은 굵은 선 으로 표현하였다. 순음이 제시된 시점인 $1000 \mathrm{~ms}$ 이후에 모 든 피험자에서 확연한 $\mathrm{ACC}$ 반응이 유발된 것을 확인할 수 있었다.

청력역치등가소음 대비 순음의 크기를 0 20 dB SNR까지 $4 \mathrm{~dB}$ 단계로 달리하여 제시하며 뇌파 반응을 취득하였을 때, 어느 크기 이하에서는 $\mathrm{ACC}$ 반응이 관찰되지 않는 것을 확인 하였다. 또한, 개별 피험자에서 취득한 $\mathrm{EEG}$ 파형을 평균 가 산하여 분석한 후, 모든 피험자의 분석된 $\mathrm{EEG}$ 파형을 평균
화한 전체 평균 파형을 Fig. 3에 표현하였다. 왼쪽 그래프는 순음이 $1000 \mathrm{~Hz}$ 인 경우의 자극 크기 별 파형을 나타낸 것이 고, 오른쪽 그래프는 순음이 $4000 \mathrm{~Hz}$ 인 경우의 파형을 나타 낸 것이다. 자극음의 신호대 잡음비(SNR)가 작아질수록 $\mathrm{ACC}$ 반응의 진폭이 점점 작아지는 것을 알 수 있었다. 각각 $4,8 \mathrm{~dB}$ $\mathrm{SNR}$ 의 자극 조건에서부터 $\mathrm{ACC}$ 반응이 유발되었고, 이 자극 단계를 역치라 말할 수 있다.

행동학적 반응 검사 결과와 전기생리학적 반응 검사 결과를 정리한 결과는 Table 1과 같다. 행동학적 반응 검사인 TEN test의 결과는 $1000,4000 \mathrm{~Hz}$ 자극음에 대해 평균 각각 $-0.60 \pm 1.35,-3.00 \pm 2.16 \mathrm{~dB} \mathrm{SNR}$ 의 값을 보였다. 전기생리 학적 반응 검사인 TEN-ACC test의 결과는 각 순음에 대해 각각 $5.60 \pm 2.07,7.20 \pm 3.16 \mathrm{~dB} \mathrm{SNR}$ 의 값을 나타냈다. TENACC test의 결과는 TEN test의 결과보다 $1000,4000 \mathrm{~Hz}$ 자극음에 대해 각각 $6.20 \mathrm{~dB} \mathrm{SNR}(\mathrm{t}=-9.86, p<0.001), 10.20$ $\mathrm{dB} \mathrm{SNR}(\mathrm{t}=-10.58, p<0.001)$ 더 큰 결과를 보였다.

연구에 참여한 10 명의 모든 피험자의 파형을 합한 전체 평

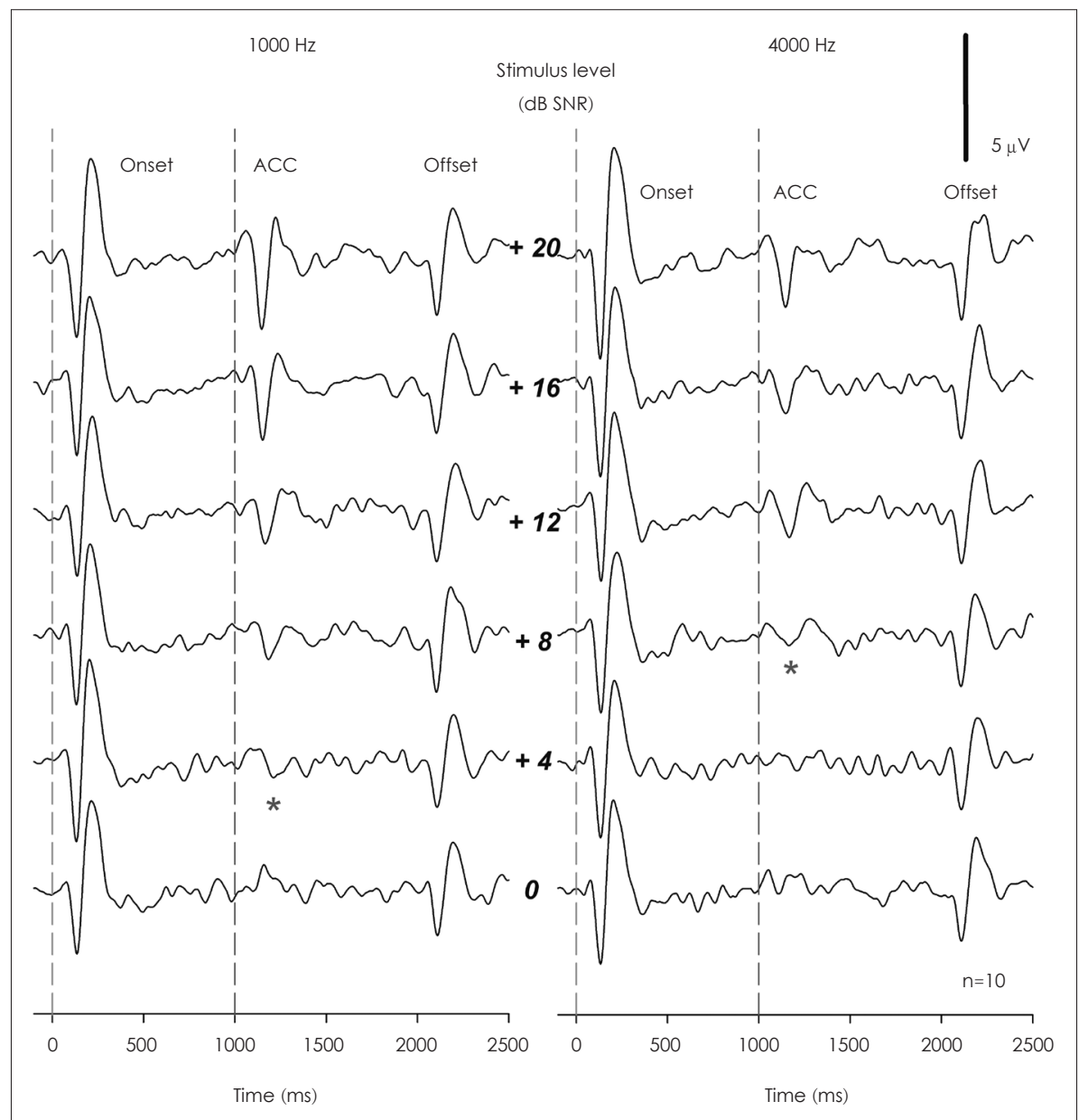

Fig. 3. The graphs indicate grand-average waveforms of each frequency condition. The robust onset and ACC responses were observed. The asterisks indicate the threshold of the ACC responses of each condition. The thresholds were $4 \mathrm{~dB}$ SNR and $8 \mathrm{~dB}$ SNR at 1000 and $4000 \mathrm{~Hz}$, respectively. SNR: signal to noise ratio, ACC: acoustic change complex. 


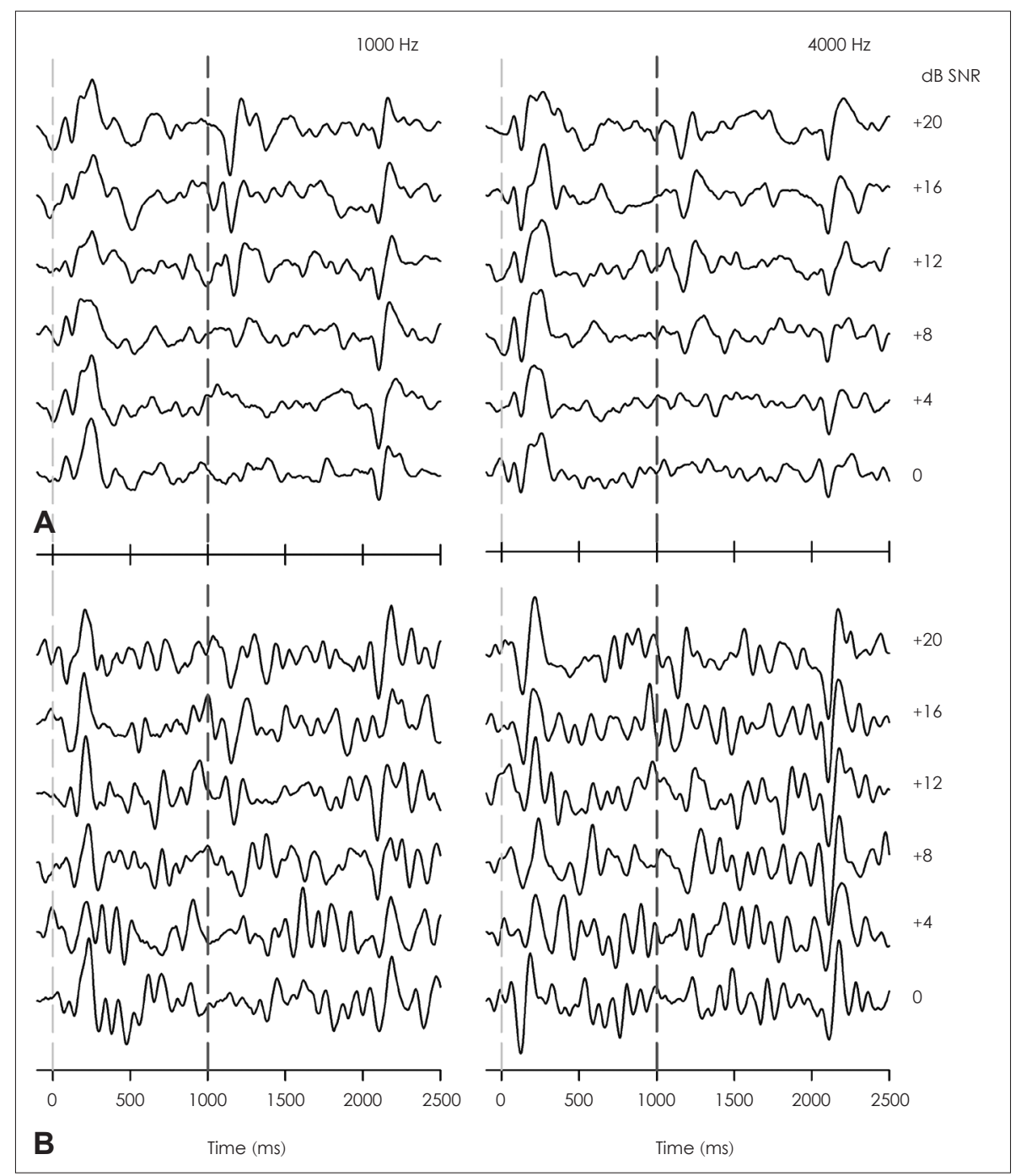

Fig. 4. Examples of a good (A) and poor (B) EEG graph. The case of a good EEG graph, ACC response can be seen clearly but in the case of a bad EEG graph, the response is very contaminated and thus hard to identify the ACC response. SNR: signal to noise ratio, EEG: electroencephalogram, ACC: acoustic change complex.

Table 1. The individual thresholds of behavioral TEN test and electrophysiological TEN-ACC test

\begin{tabular}{|c|c|c|c|c|c|c|}
\hline \multirow{2}{*}{ Subject } & \multirow{2}{*}{ Sex } & \multirow{2}{*}{ Age } & \multicolumn{2}{|c|}{ TEN test (dB SNR) } & \multicolumn{2}{|c|}{ TEN-ACC test (dB SNR) } \\
\hline & & & $1000 \mathrm{~Hz}$ & $4000 \mathrm{~Hz}$ & $1000 \mathrm{~Hz}$ & $4000 \mathrm{~Hz}$ \\
\hline 1 & Male & 30 & 0 & -4 & 8 & 8 \\
\hline 2 & Female & 31 & -2 & -4 & 4 & 12 \\
\hline 3 & Male & 20 & 2 & 0 & 8 & 12 \\
\hline 4 & Male & 33 & -2 & -2 & 8 & 4 \\
\hline 5 & Female & 23 & -2 & -6 & 4 & 4 \\
\hline 6 & Female & 23 & 0 & 0 & 4 & 8 \\
\hline 7 & Female & 30 & -2 & -6 & 4 & 4 \\
\hline 8 & Male & 26 & 0 & -4 & 4 & 8 \\
\hline 9 & Female & 29 & 0 & -2 & 4 & 4 \\
\hline 10 & Female & 33 & 0 & -2 & 8 & 8 \\
\hline Mean & & 27.22 & -0.60 & -3.00 & 5.60 & 7.20 \\
\hline SD & & 4.54 & 1.35 & 2.16 & 2.07 & 3.16 \\
\hline
\end{tabular}

TEN: threshold-equalizing noise, ACC: acoustic change complex, SNR: signal to noise ratio, SD: standard deviation 
균 파형에서는 ACC 반응이 뚜렷하게 관찰되었으나, 개별 파 형에서는 파형이 깔끔하게 잘 나온 경우와 그렇지 못한 경우 로 나누어 졌다. 각 주파수 대역에서 순음의 크기를 $4 \mathrm{~dB}$ 단 계씩 조절하면서 제시하여 취득한 개인의 파형을 다음 그림 에서 나타내었다(Fig. 4). Fig. 4A는 좋은 결과의 예, Fig. 4B 는 안 좋은 결과의 예를 보여준다. Fig. $4 \mathrm{~A}$ 그래프의 경우 배 경잡음으로 청력 역치등가소음이 있으면서 순음이 제시된 시점인 $1000 \mathrm{~ms}$ 후에 $\mathrm{ACC}$ 반응이 뚜렷하게 나오는 것을 볼 수 있고, 각 순음 조건 $1000,4000 \mathrm{~Hz}$ 에서 역치는 각각 8, 8 $\mathrm{dB} \mathrm{SNR}$ 로 판단하였다. 순음의 크기가 작아져 역치에 가까 워질수록 $\mathrm{ACC}$ 반응의 진폭이 작아진다. Fig. $4 \mathrm{~B}$ 그래프의 경우에는 SNR이 큰 조건에서는 $\mathrm{ACC}$ 반응이 있음을 판단 할 수 있지만, 순음의 크기가 작아져 SNR이 작아지면 주변 잡음과 $\mathrm{ACC}$ 반응의 진폭과의 차이가 크지 않아 ACC 반응 의 유무를 판단하기 어렵다. 이렇듯, 측정한 뇌파의 질이 피 험자마다 크게 차이가 나는 한계를 발견하였고, 이는 ACC 반응 유무 결정의 오류를 높일 것이라 우려 된다.

\section{고 찰}

달팽이관 내에 존재하는 내유모세포 또는 청신경의 손상으 로 인해 소리 전달 기능을 상실한 와우소실영역은 난청의 정 도가 심해질수록 발생할 확률이 높아지며, 중고도 난청 환자 에서 약 $60 \%$ 정도의 와우소실영역이 한 개 이상의 주파수에 서 존재한다는 최근 연구 결과도 발표되었다. ${ }^{13)}$ 와우소실영역 의 진단은 임상적으로 중요한 의의를 지니는데 특히 보청기 사용자의 보청기 적합과정에서 와우소실영역이 있는 해당 주파수 대역의 증폭 여부 등을 결정하는 데 도움을 줄 수 있 고, 최근에는 돌발성 난청 환자에서 와우소실영역의 존재 여 부가 예후 인자로 작용한다는 것도 발표되었다. ${ }^{14)} \mathrm{Baer}$ 등 ${ }^{15)}$ 은 고주파수 대역 난청 환자를 대상으로 와우소실영역의 유 무에 의한 보청기 고주파수 대역 증폭 효과에 대해 비교하였 는데, 와우소실영역이 없는 그룹에서는 고주파수 신호 정보 가 증폭될수록 보청기 적합 후 결과가 좋았으나, 와우소실영 역이 있는 그룹에서는 고주파수 신호 정보를 증폭시켜준다 하더라도 어음인지에 도움을 받지 못하였다. 즉, 고주파수 대 역난청 환자가 어떠한 주파수 이상의 부분에 와우소실영역 이 있으면 그 주파수를 기준으로 1.5 2배 이상의 주파수 정 보의 증폭에 대한 효과는 미미한 것을 보여주고 있다.

다른 연구 ${ }^{4}$ 에서도 저주파수 대역의 난청 환자를 대상으로 저주파수 대역 와우소실영역의 유무에 따라 유사한 연구를 진행하였고, 와우소실영역이 시작되는 주파수의 약 0.57 배 까 지의 주파수 대역의 증폭은 오히려 정답률을 감소시키는 결
과를 보였다. 심지어 와우소실영역이 존재하는 저주파수 대 역의 정보를 없애는 것이 더 좋은 정답률을 나타내었다. 이 와 같은 연구의 결과들은 와우소실영역에 대한 정보가 보청 기 적합 시 중요한 요소로 작용할 수 있다는 것을 보여준다.

와우소실영역의 탐지는 임상적으로 청력역치등가소음 검 사를 활용하여 진행하는데 이러한 검사는 행동학적인 반응 을 통해서만 진행할 수 있기 때문에 객관적인 와우소실영역 탐지검사법은 아니다. 본 연구에서는 전기생리학적 방법을 이용하여 달팽이관의 와우소실영역을 판단하기 위한 객관적 인 방법을 제안하고 그 방법의 가능성을 탐구하였다.

전기생리학적 방법으로 많은 연구에서 뇌파를 많이 활용하 고, ACC 반응 또한 어떠한 변화에 의해 유발된다는 특성을 활용하여 청각 능력을 평가하기 위한 객관적인 지표로써 제 안하는 연구들이 있다. ${ }^{9-11)}$ 따라서, 본 연구에서 전기생리학 적 지표로 $\mathrm{ACC}$ 반응을 활용하였으며, 객관적 검사의 검사 명은 TEN-ACC 검사라고 명명하였다. 연구 결과 모든 피험 자에게서 TEN-ACC 자극음을 제시하였을 때, 뚜렷한 ACC 반응을 보이는 것을 확인하였다. 자극음 제시 직후 나타나는 $\mathrm{P} 1-\mathrm{N} 1-\mathrm{P} 2$ 복합체와 순음 자극 시점인 $1000 \mathrm{~ms}$ 후에 관찰 되는 뚜렷한 P1-N1-P2 복합체는 그 형태가 기존 문헌에 보 고된 결과와 유사하다. ${ }^{911,16)}$ 자극음의 크기를 조정하며 제시 함으로써, 기존 문헌 보고와 유사하게 자극음의 크기가 작아 질수록 $\mathrm{ACC}$ 반응의 진폭이 작아지는 것을 확인하였고, 이 를 이용하여 역치를 평가하였다.

모든 피험자에게서 ACC 반응을 확인하였지만, TEN test 의 역치보다 TEN-ACC test의 역치가 상당히 크게 나왔다. 일반적으로 행동 반응 검사보다 전기생리학적 검사의 역치가 더 크게 측정된다고 알려져 있으나, 본 연구에서의 $4 \mathrm{kHz}$ 의 결과는 $10 \mathrm{~dB}$ 이상 차이 나는 것으로 보아 역치 부근에서의 뇌파에서 $\mathrm{ACC}$ 반응이 주변 잡음에 묻힌 것으로 추정된다. 또는, 자극음 크기 단계가 $4 \mathrm{~dB} \mathrm{SNR}$ 로 행동학적 검사의 단 계인 $2 \mathrm{~dB} \mathrm{SNR}$ 보다 두 배 크다. 따라서 검사를 진행하지 않 은 사이 단계에서 역치가 측정될 수 있을 것이라 사료된다. 측정한 뇌파의 질이 피험자마다 차이가 크게 나는 부분을 조금이라도 개선하기 위해서, 추후 검사 환경에서는 뇌파의 잡음을 줄이기 위한 파라미터 변경 및 조정을 통해 최적의 파라 미터를 찾는 것이 필요하다.

본 연구에서는 TEN-ACC 검사를 개발하기 위한 초기 단 계로써, TEN test의 음원을 활용하여 ACC 반응을 처음으 로 탐구한 것에 의의가 있다. 본 연구는 최초로 시행된 연구 로서 그 의의가 있으며, 특히 그동안 와우소실영역을 객관적 으로 측정하기 위한 많은 시도 속에 비록 정상인을 대상으로 연구한 결과이나 수정된 새로운 자극음을 활용하여 객관적 
인 $\mathrm{ACC}$ 반응을 이끌어낸 것은 고무적인 결과라 할 수 있다.

$\mathrm{TEN}$ 음원을 이용하여 ACC 반응이 유발되고, 자극음의 크기에 따라 $\mathrm{ACC}$ 반응의 역치를 측정할 수 있다면, 피험자 의 청력 정도에 따라 그 역치가 달라질 것이라 추정하고, 그 결과에 따라 와우소실영역의 존재 유무를 판단할 수 있을 것이라고 기대된다. 예를 들어, 측정한 $\mathrm{ACC}$ 반응의 평균 역 치가 정상인에서 $4 \mathrm{~dB} \mathrm{SNR}$, 와우소실영역이 없는 난청인에 서는 $8 \mathrm{~dB} \mathrm{SNR}$, 와우소실영역이 있는 난청인에서는 $16 \mathrm{~dB}$ $\mathrm{SNR}$ 의 자극 조건에서 관찰될 때 우리는 와우소실영역을 평 가하기 위한 객관적인 $\mathrm{TEN}-\mathrm{ACC}$ 검사 결과로, 와우소실영 역이 있는 난청인 그룹의 역치의 한 단계 아래 단계인 $12 \mathrm{~dB}$ $\mathrm{SNR}$ 의 신호대 잡음비를 갖는 자극음을 와우소실영역을 판 단하기 위한 기준으로 제안할 수 있다. 즉, $12 \mathrm{~dB} \mathrm{SNR}$ 의 자 극음에서 반응이 나오는 경우 와우소실영역이 없다고 판단 할 수 있고, 반응이 나오지 않는 경우 와우소실영역이 있다고 판단할 수 있을 것이다. 본 예는 대략적인 값을 예로 든 것으 로, 추후 다양한 집단에서 진행한 연구 결과를 통해, 정확한 기준값을 제안할 수 있을 것이라 사료된다.

앞서 언급한 바와 같이, 본 임상 연구 결과는 정상군에 대 해서만 데이터를 습득하였는데 TEN-ACC 검사는 와우소실 영역을 탐지하는 것이 목적이므로, 와우소실영역을 판단하 기 위한 근거 데이터 습득을 위해 추후 와우소실영역이 없는 난청인과 있는 난청인을 대상으로 한 임상 연구가 필요하고, 더 나아가 임상 적용을 위해서 행동 반응검사를 시행할 수 없는 피험자를 위한 연구도 필요하다.

\section{REFERENCES}

1) Moore BC. Dead regions in the cochlea: diagnosis, perceptual consequences, and implications for the fitting of hearing AIDS. Trends Amplif 2001;5(1):1-34.

2) Moore BC. Dead regions in the cochlea: conceptual foundations, diagnosis, and clinical applications. Ear Hear 2004;25(2):98-116.

3) Vinay, Baer T, Moore BC. Speech recognition in noise as a function of highpass-filter cutoff frequency for people with and without lowfrequency cochlear dead regions. J Acoust Soc Am 2008;123 (2):606-9.

4) Vinay, Moore BC. Speech recognition as a function of high-pass filter cutoff frequency for people with and without low-frequency cochlear dead regions. J Acoust Soc Am 2007;122(1):542-53.

5) Cox RM, Johnson JA, Alexander GC. Implications of high-frequency cochlear dead regions for fitting hearing aids to adults with mild to moderately severe hearing loss. Ear Hear 2012;33(5):573-87.

6) Moore BC, Huss M, Vickers DA, Glasberg BR, Alcántara JI. A test for the diagnosis of dead regions in the cochlea. Br J Audiol 2000; 34(4):205-24.

7) Moore BC, Creeke S, Glasberg BR, Stone MA, Sek A. A version of the TEN test for use with ER-3A insert earphones. Ear Hear 2012;33(4): 554-7.

8) Martin BA, Boothroyd A. Cortical, auditory, event-related potentials in response to periodic and aperiodic stimuli with the same spectral envelope. Ear Hear 1999;20(1):33-44.

9) Martin BA, Boothroyd A. Cortical, auditory, evoked potentials in response to changes of spectrum and amplitude. J Acoust Soc Am 2000;107(4):2155-61.

10) Ostroff JM, Martin BA, Boothroyd A. Cortical evoked response to acoustic change within a syllable. Ear Hear 1998;19(4):290-7.

11) $\mathrm{He} \mathrm{S}$, Grose JH, Buchman CA. Auditory discrimination: the relationship between psychophysical and electrophysiological measures. Int J Audiol 2012;51(10):771-82.

12) Martin BA, Tremblay KL, Korczak P. Speech evoked potentials: from the laboratory to the clinic. Ear Hear 2008;29(3):285-313.

13) Ahadi M, Milani M, Malayeri S. Prevalence of cochlear dead regions in moderate to severe sensorineural hearing impaired children. Int J Pediatr Otorhinolaryngol 2015;79(8):1362-5.

14) Choi JE, Lee JJ, Chung WH, Cho YS, Hong SH, Moon IJ. Clinical implication of the threshold equalizing noise test in patients with sudden sensorineural hearing loss. Otol Neurotol 2016;37(10):1503-9.

15) Baer T, Moore BC, Kluk K. Effects of low pass filtering on the intelligibility of speech in noise for people with and without dead regions at high frequencies. J Acoust Soc Am 2002;112(3 Pt 1):113344.

16) Harris KC, Mills JH, He NJ, Dubno JR. Age-related differences in sensitivity to small changes in frequency assessed with cortical evoked potentials. Hear Res 2008;243(1-2):47-56. 